GLOBAL JOURNAL OF AGRICULTURAL SCIENCES VOL. 19, 2020: 45-49

COPYRIGHT@ BACHUDO SCIENCE CO. LTD PRINTED IN NIGERIA ISSN 1596-2903 www.globaljournalseries.com, Email: info@globaljournalseries.com

\title{
ASSESSMENT OF ADOPTION AND UTILISATION OF SUPERIOR RICE GERMPLASM BY SMALLHOLDER FARMERS IN FOUR RICE PRODUCING ZONES OF NIGERIA
}

ALAMU. O., ALADELE, S. E., OKERE, A. U., OSEWA, S. O., OLUBIYI, M. R., LEE, M., JOLAIYA , O. B. AND HASSAN, O. K. (Received 9 January 2020; Revision Accepted 20 February 2020)

\begin{abstract}
Conservation and sustainable use of plant genetic resources is essential to the sustainable development of agricultural production and rural in production zones in Nigeria. This study, therefore investigated the utilisation of recently released superior rice germplasm among smallholder farmers in Nigeria. A post- crop varietal release impact assessment was conducted in Oyo, Ekiti, Kwara and Ebonyi states of Nigeria in 2019. Structured questionnaires were administered to 120 farmers using a simple random sampling technique. Result from the study revealed that rice farmers are mainly males, middle aged, married, with some form of education. They have medium (3-6 household member) household size with longer years of farming experiences. Inadequate capital and limited credit facilities, plant disease, birds and insect infestation are the major constraints encountered by the farmers. Result of the correlation analysis shows that there was no significant relationship between sources of planting materials and frequently planted varieties $(r=0.100$ and $p=0.786)$. However, there was significant relationship between production constraints and frequently planted varieties $(r=0.010$ and $p=0.648)$. It is recommended that more channels of credit facilities should be provided to rice farmers by governments at various levels to improve their level productivity.
\end{abstract}

KEYWORDS: Rice, adoption, genetic resources, utilisation, smallholder farmers

\section{INTRODUCTION}

Nigeria is endowed with abundant plant genetic resources with substantial potentials for agricultural production. It ranks first among the leading agricultural producers in the West Africa sub-region. Rice (Oryza sativa L.) is a cereal belonging to the family Gramineae, a large monocotyledonous family of some 600 genera and around 10,000 species. It is one of the leading food crops in the world and the most consumed staple food in Nigeria (Hawksworth, 1985). Rice is best grown in lands with moderately high water holding-capacity or swampy lands.

Rice is a major source of carbohydrates, minerals, and vitamins which provides energy in the human body.
Rice, wheat, maize are the three leading food crops in the world; together they directly supply more than $42 \%$ of all calories consumed by the entire human population (GRiSP, 2013).The crop is third highest in global food production, after wheat and maize (Romain, 2001; FAOSTAT, 2012). In Nigeria, over sixty seven (67) improved rice varieties bred by national institutes, private seed companies and Africa Rice (a CGIAR Centre) have been released and registered by the National Crop Varietal Release Committee (NACGRAB, 2014). However, majority of the rice farmers source their seed for planting from saved seeds and closed relatives. Additionally, the extent of distribution and utilisation of these improved rice germplasm by smallholder farmers in Nigeria is relatively unknown. Therefore, this study

Alamu. O., National Centre for Genetic Resources and Biotechnology PMB 5382 Moor Plantation Ibadan, Nigeria.
Aladele, S. E., National Centre for Genetic Resources and Biotechnology PMB 5382 Moor Plantation Ibadan, Nigeria.
Okere, A. U., National Centre for Genetic Resources and Biotechnology PMB 5382 Moor Plantation Ibadan, Nigeria.
Osewa, S. O., National Centre for Genetic Resources and Biotechnology PMB 5382 Moor Plantation Ibadan, Nigeria.
Olubiyi, M. R., National Centre for Genetic Resources and Biotechnology PMB 5382 Moor Plantation Ibadan, Nigeria.
Lee, M., National Centre for Genetic Resources and Biotechnology PMB 5382 Moor Plantation Ibadan, Nigeria.
Jolaiya, O. B., National Agrobiodiversity Center (NAC), Rural Development Administration (RDA), Republic of Korea.
Hassan, O. K., National Centre for Genetic Resources and Biotechnology PMB 5382 Moor Plantation Ibadan, Nigeria.

(C) 2020 Bachudo Science Co. Ltd. This work is licensed under Creative Common Attribute 4.0 International license 
seeks to focus addressing gaps in availability of quality planting materials for rice farmers, and enhance the utilisation and adoption of rice germplasm in the rice growing zones of the country. The following questions were answered by this study.

1. What are the selected personal characteristics of rice farmers in the study area?

2. What are rice farmer's sources of planting materials in the area?

3. What are the major production constraints of rice farmers in the area?

4. What are the frequently planted rice varieties by the farmers planted in the study area?

Hypotheses of the study

Ho1: There is no significant relationship between Sources of planting materials and frequently planted varieties.

Ho2: There is no significant relationship between production constraints and frequently planted varieties.

\section{METHODOLOGY}

The study was carried out in Oyo, Kwara, Ekiti and Ebonyi States of Nigeria located within forest and southern guinea savannah ecological zones of the country. The States surveyed constitutes part of rice producing states of Nigeria. The population for the study comprised all rice farmers in the four States. Two (2) Local Government Areas (LGAs) were randomly selected from each of the 4 states, making a total of eight (8) LGAs. A snow ball sampling technique was used to generate 15 rice farmers from each of the LGA to give a total of 120 respondents. The data for the study were collected through interview schedules with the rice farmers. The data collected were analyzed using both descriptive (frequency counts, percentages and means) and inferential statistics (chi-square). The independent variables for the study include selected personal characteristics, planting materials sources, and production constraints. The dependent variable is rice farmers planting varieties.

\section{RESULTS AND DISCUSSION SOCIO-ECONOMIC CHARACTERISTICS OF RICE FARMERS}

Findings in Table 1 showed that $35.0 \%$ of the respondents were between the ages of 31 years and 40years, while $5.8 \%$ of the respondents were above 60 years of age. The mean age was 33.5years. This implies that rice producers in the study areas were in their active and productive age which tends to positively influence their performance on the field. The relatively young age might make the farmers more receptive to new techniques of farming (Eddy, 2000). The results also showed that majority $(88.3 \%)$ of the respondents were male while the remaining $11.7 \%$ were female. Furthermore, results in Table 1 showed that majority $(85.8 \%)$ of the respondents were married while only $14.2 \%$ were single indicating that marriage confers a sense of responsibility among the farmers in the areas. $37.5 \%$ of the respondents had secondary school education while $27.3 \%$ and $11.7 \%$ had primary and tertiary schools education which implies that the literacy level in this study area is relatively high. This might help the farmers in sourcing and adopting improved rice varieties and also aid extension works. Marriage and education are of significance as they influence an individual's preference for source of information explored and their varied information needs (World Bank, 2004; FAO, 2000). Household size implies the total number of people staying under a roof and being fed. Majority $(71.7 \%)$ of the respondents had between 36 household, which should presumably result in increased production. Table 1 showed that less than half $(43.3 \%)$ of the respondents cultivated between 2-5 acres of farmland. This shows that most of the rice farmers operated on a small scale enterprise. This result corresponds with the findings of Kolawole (2007) that agricultural practice in Nigeria is usually carried out by smallholder farmers scattered over wide expanse of land area. Also, more than half $(51.7 \%)$ of the respondents had grown rice for more than 11 years which implies that farmers in the study area have had relatively longer period of farming experience. Finally, Table 1 revealed that $64.2 \%$ of the respondents were aware of recently released and registered rice varieties.

\section{SOURCES OF PLANTING MATERIALS}

The result of the findings in Table 2 showed the distribution of respondents according to the sources of planting materials. Less than half $(38.3 \%)$ of the respondents got their planting seeds from the previously harvested materials and $28.3 \%$ of the respondents got their planting seeds from agro-input dealers, while only $6.7 \%$ of the respondents got their planting seeds from Agricultural Development Programme (ADP). This is an indication that rice farmers in the study area might not have access to improved seeds. 
Table 1: Distribution of respondents by socio-economic characteristics $(n=120)$

\begin{tabular}{|c|c|c|}
\hline $\begin{array}{l}\text { Variables } \\
\text { (Age) }\end{array}$ & Frequencies & Percentages \\
\hline$\leq 20$ & 8 & 6.7 \\
\hline $21-30$ & 31 & 25.8 \\
\hline $31-40$ & 42 & 35.0 \\
\hline $41-50$ & 23 & 19.2 \\
\hline $51-60$ & 9 & 7.5 \\
\hline Above 60 & 7 & 5.8 \\
\hline \multicolumn{3}{|l|}{ Gender } \\
\hline Male & 106 & 88.3 \\
\hline Female & 14 & 11.7 \\
\hline \multicolumn{3}{|l|}{ Marital Status } \\
\hline Married & 103 & 85.8 \\
\hline Single & 17 & 14.2 \\
\hline Divorced & - & - \\
\hline Widow & - & - \\
\hline \multicolumn{3}{|l|}{ Educational Attainment } \\
\hline Non-formal education & 28 & 23.3 \\
\hline Primary education & 33 & 27.5 \\
\hline Secondary education & 45 & 37.5 \\
\hline Tertiary education & 14 & 11.7 \\
\hline \multicolumn{3}{|l|}{ Household Size } \\
\hline$<3$ & 32 & 26.7 \\
\hline $3-6$ & 86 & 71.7 \\
\hline $7-10$ & 2 & 1.7 \\
\hline Above 10 & - & - \\
\hline \multicolumn{3}{|l|}{ Farm Size } \\
\hline$\leq 2$ acres & 30 & 25.0 \\
\hline 2-5 Acres & 52 & 43.3 \\
\hline 5-8 Acres & 22 & 18.3 \\
\hline 8-11 Acres & 11 & 9.2 \\
\hline Above 11 Acres & 5 & 4.2 \\
\hline \multicolumn{3}{|c|}{ Farming Experience (Years) } \\
\hline $1-5$ & 33 & 27.5 \\
\hline $6-10$ & 25 & 20.8 \\
\hline 11 and above & 62 & 51.7 \\
\hline \multicolumn{3}{|c|}{ Awareness of recently registered varieties } \\
\hline Yes & 77 & 64.2 \\
\hline No & 43 & 35.8 \\
\hline
\end{tabular}

Source: Field survey, 2018

Table 2: Distribution of respondents showing sources of planting materials $(n=120)$

\begin{tabular}{lll}
\hline Sources & Frequencies & Percentages \\
\hline Saved seed & 46 & 38.3 \\
Farmers/Relative & 23 & 19.2 \\
Agro-input dealer & 34 & 28.3 \\
Agricultural Development Programme (ADP) & 8 & 6.7 \\
Ministry of Agriculture & 9 & 7.5 \\
\hline
\end{tabular}

Source: Field survey, 2018

\section{Major constraints facing rice farmers}

Data in Table 3 revealed that $32.3 \%$ of the respondents agreed that inadequate capital and credit facilities are the major constraints in rice production as it is often the case among rural farmers as reflected by Oyesola et al., (2010). Table 4 also indicates that disease, insect pest and bird infestation (31.7\%) as other constraints affecting the production of rice which is in agreement with the findings of Okelola et al., (2007). Knowledge of technical know-how (3.3\%) was reported as a mild constraint, while $(1.7 \%)$ of the respondents indicated lack of storage facilities as major constrains as they alternatively spread their planting seeds on the floor of the room or store . 
Table 3: Distribution showing respondents' constraints

\begin{tabular}{lll}
\hline Constraints & Frequencies & Percentages \\
\hline Disease, pest, bird and insect infestation & 38 & 31.7 \\
High cost of input and production & 29 & 24.2 \\
Unavailability of pure lines & 21 & 17.5 \\
Poor transportation system & 7 & 5.8 \\
Lack of technical know-how & 4 & 3.3 \\
Inadequate capital and credit facilities & 39 & 5.8 \\
Flooding & 7 & 15.0 \\
Strenuous and laborious production and processing activities & 18 & 5.0 \\
Land tenure system & 6 & 4.2 \\
Lack of farm machinery and equipment & 5 & 9.2 \\
Unfavourable weather condition & 11 & 1.7 \\
Lack of storage facilities & 2 & \\
\hline
\end{tabular}

Source: Field survey, 2018

\section{Frequently planted rice varieties}

Table 4 reflected that $39.2 \%$ of the respondents claimed to have planted local rice germplasm and $36.7 \%$ of the respondents claimed that they planted FARO 44, while only $1.7 \%$ of the respondents planted FARO 57 . This implies that even though farmers in the study area might be aware of the improved rice varieties but did not source or have little or limited access to it.

Table 4: Distribution of respondents showing frequently planted rice varieties $(n=120)$

\begin{tabular}{lll}
\hline Varieties & Frequencies & Percentages \\
\hline FARO 44 & 44 & 36.7 \\
FARO 45 & 4 & 3.3 \\
FARO 52 & 13 & 10.8 \\
FARO 54 & 4 & 3.3 \\
FARO 57 & 2 & 1.7 \\
FARO 66 & 6 & 5.0 \\
Local & 47 & 39.2 \\
\hline
\end{tabular}

Source: Field survey, 2018

Results in Table 5 showed that majority (94.2\%) of the respondents claimed that they were planting lowland rice while only $5.8 \%$ were planting upland rice varieties. This implies that the farmers were putting lowland or swampy lands hitherto not cultivated for other arable crops into use for sustainability of their farming enterprise.

Table 5: Distribution showing respondents' ecology cultivated

\begin{tabular}{lll}
\hline Ecology & Frequencies & Percentages \\
\hline Lowland & 113 & 94.2 \\
Upland & 7 & 5.8 \\
\hline
\end{tabular}

Source: Field survey, 2018

Hypothesis One $\left(\mathrm{Ho}_{1}\right)$ : There is no significant relationship between sources of planting materials and farmers frequently planted varieties. Result in Table 6 shows that frequently planted varieties is not dependent on the sources of planting materials. This implies that the sources of farmers planting material do not have any effect on their choice of varieties.

Table 6: Results of Correlation Analysis

\begin{tabular}{lllll}
\hline Variables & r-value & p-value & Remarks & Decision \\
\hline Source of planting materials/planted varieties & 0.100 & 0.786 & $\mathrm{NS}$ & $\mathrm{Accept} \mathrm{Ho}_{1}$ \\
Constraints/planted varieties & 0.010 & 0.648 & $\mathrm{NS}$ & $\mathrm{Accept} \mathrm{Ho}_{2}$ \\
\hline
\end{tabular}

Source: Field survey, 2018

$p>0.05=$ not significant (NS), $p<0.05=$ significant 
Hypothesis One $\left(\mathrm{Ho}_{2}\right)$ : There is no significant relationship between constraints and farmers frequently planted varieties. Table 6 reveals that varieties planted by the farmers was not dependent on the constraints. This suggest that the challenges faced by the farmers do not affect their choice of varieties planted.

\section{CONCLUSION}

It is concluded that the rice farmers in the production zones evaluated are mainly males, middle aged, married, with some form of education, have medium household size, and have years of farming experiences. They are quite aware of improved and recently released varieties, even though they still plant local varieties, obtained their planting seeds from previously harvested seeds. Moreover, inadequate capital and limited credit facilities, and diseases, insect pest and birds infestation are the major constraints encountered by the farmers. Non-availability of improved varieties is regarded as a mild challenge. Finally, the choice of farmers planting varieties is neither affected by sources of planting materials or the production constraints.

\section{RECOMMENDATIONS}

1. It is recommended that credit facilities and incentives should be provided for smallholder farmers by government at various levels to enhance production of superior rice varieties in the zones.

2. Government, non-government organizations/agencies and community based organizations (CBOs) should assist in educating the rice farmers through virile and effective agricultural extension system and advocacy in facilitating adoption of improved and recently released varieties.

3. There should be synergy of activities among relevant stakeholders in agri-input value chain so as to make superior rice germplasm and varieties available to users of genetic resources and smallholder farmers in Nigeria

\section{ACKNOWLEDGEMENTS}

The authors are grateful for the support received from the Director/CEO of National Centre of Genetic Resources and Biotechnology (NACGRAB) and Rural Development Administration (RDA), Republic of Korea through Korea-Africa Food and Agriculture Initiative (KAFACl) funded project on Improvement of Technology on Conservation of Genetic Resources.

\section{REFERENCES}

Eddy, O., 2002. Extension needs of women farmers in Igueben and Esan North East Local Government Areas of Edo State, Nigeria. Africa Development. 28 (2):116-126.

Food and Agricultural Organisation of United Nations FAO, 2000. Year Book Production, Rome, Italy.

Global Rice Science Partnership, 2013. Rice almanac, $4^{\text {th }}$ edition. Los Banos (Philippines): International Rice ResearchInstitute.283pp

Hawksworth, D. L., 1985. Foreword. In S. H. Du, ed. Rice diseases. CMI Slough, UK, CAB. 380pp.

International Plant Genetic Resources Institute, 2002. Neglected and underutilized plant species: Strategic action plan of the International Plant Genetic Resources Institute (IPGRI), Rome.

Kolawole, O. O., 2007. Economic efficiency of small scale food crop production in Nigeria. Journal for Social Sciences 14(2): 123-130.

NACGRAB, 2014 .Catalogue of Crop Varieties Released and Registered in Nigeria Vol. 6 106pp.

Okelola, F. S. Adebisi, M. A., Kehinde, O. B. and Ajala, M. O., 2007. Genotypic And Phenotypic Variability For Seed Vigour Traits And Seed Yield In West African Rice (Oryza sativa L.) Genotypes .Journal of American Science 3 (3):1-8

Oyesola, O.B. and Kadiri, T.S., 2010. Effects of Rural Urban Interaction on Socio-Economic Status of Rural Dwellers in Oyo State, Nigeria. Global Approaches to Extension Practice, 6 (2):110.

Romain, H.R., 2001.Crop production in Tropical Africa. DGIC, Brussels, Belgum, 1540pp. 